\title{
Pulmonary veno-occlusive disease: a rare cause of pulmonary hypertension in systemic sclerosis. Case presentation and review of the literature
}

\author{
ANA MARIA DARABAN ${ }^{1,2}$, ROXANA ENACHE $^{2}$, L. PREDESCU ${ }^{3}$, P. PLATON ${ }^{3}$, \\ T. CONSTANTINESCU ${ }^{2,4}$, CARINA MIHAI ${ }^{2,5}$, I.M. COMAN ${ }^{2,3}$, \\ CARMEN GINGHINÄ ${ }^{2,3}$, RUXANDRA JURCUT \\ ${ }^{1}$ Clinical Emergency Hospital Bucharest, Romania \\ 2“Carol Davila” University of Medicine and Pharmacy, Bucharest, Romania \\ 3“C.C. Iliescu” Emergency Institute for Cardiovascular Diseases, Bucharest, Romania \\ 4"Prof. Dr. Marius Nasta” Pneumology Institute, Bucharest, Romania \\ 5"Cantacuzino" Clinical Hospital, Bucharest, Romania
}

\begin{abstract}
Pulmonary veno-occlusive disease (PVOD) is a rare cause of pulmonary arterial hypertension $(\mathrm{PAH})$. Because of the similar clinical picture of dyspnea on exertion and signs of right heart failure, PVOD is difficult to distinguish from idiopathic PAH. However, the distinction is mandatory because PVOD has a worse prognosis and, more importantly, the administration of PAH specific therapy (vasodilators) can precipitate severe acute pulmonary oedema. We present a challenging case of PAH in a patient with systemic sclerosis in whom a marked decrease in functional capacity after the initiation of bosentan therapy led to the diagnosis of PVOD. Management of PVOD patients is challenging and referral for lung transplantation should be done at the moment of diagnosis.
\end{abstract}

Key words: Pulmonary arterial hypertension; pulmonary venoocclusive disease, Systemic sclerosis.

\section{INTRODUCTION}

Pulmonary veno-occlusive disease (PVOD) is a rare cause of pulmonary arterial hypertension (PAH) and, based on its clinical, imaging and outcome particularities, it has been classified as a distinctive group of PAH - Group 1' according to the 2013 Nice updated clinical classification of pulmonary hypertension [1,2]. Because of the similar clinical picture of dyspnea on exertion and signs of right heart failure, PVOD is difficult to distinguish from idiopathic PAH (IPAH) and it has been reported to account for $5-10 \%$ of histological forms of cases initially considered to be IPAH [3]. However, the distinction is mandatory because PVOD has a worse prognosis and, more importantly, the administration of PAH specific therapy (vasodilators) can precipitate severe acute pulmonary oedema [3]. Group 1' PAH can be either idiopathic or associated with several conditions such as connective tissue disease [4,5], HIV infection [6], bone marrow transplantation [7,8], sarcoidosis [9] and pulmonary Langerhans cell granulomatosis [10]. In the past years, the association between PVOD and systemic sclerosis has been reported with increased frequency [3]. Systemic sclerosis ( $\mathrm{SSc}$ ) is a connective tissue disease characterised by small vessel arterial vasculopathy, inflammatory and immunological processes leading to the final result of skin thickening and fibrosis as well as internal organs involvement [11]. There are two major subtypes of SSc: limited cutaneous SS (1-SSc), involving the skin of the face, neck and areas distal to the elbows and knees, and associated with the CREST syndrome (Calcinosis, Raynaud's syndrome, Esophageal dysmotility, Sclerodactyly, Telangiectasia) and the diffuse cutaneous SSc (d-SSc) involving a more extensive skin area [12]. Both of these subtypes are associated with the development of SSc - associated PAH (Group 1, Subtype 1.4.1 of the Dana Point Classification) and currently, all SSc patients undergo annual screening for $\mathrm{PH}$ and, in the case of PAH development they are treated according to the European guidelines with specific PAH vasodilators $[2,13,14]$. However, due to the SSc association with PAH, PVOD can remain undiagnosed in these particular patients. As such, the development of acute dyspnea with the clinical and radiological picture of acute pulmonary oedema in the absence of left ventricular (LV) 
disease should prompt imaging testing for the diagnosis of PVOD. Thus, in order to raise the awareness about PVOD in SSc and its clinical and therapeutic consequences we report a challenging case of PH in an SSc patient in whom high clinical suspicion led to the correct diagnosis.

\section{CASE REPORT}

We present the case of a 48 years old female patient admitted to our clinic for pulmonary hypertension severity evaluation. She was diagnosed 10 years earlier with 1-SSC and developed over time the clinical picture of an incomplete CREST syndrome (with Raynaud's, esophageal involvement, sclerodactily and telangiectasias). She has a history of pulmonary tuberculosis which was fully treated 8 years ago. She never smoked and has no toxic exposure whatsoever.

At the moment of the first presentation the patient had dyspnoea at moderate exertion.

Clinical examination revealed the typical clinical features of CREST syndrome - she had numerous telangiectasia on her face, neck and anterior thorax, shiny, taut, and thickened skin on the face, forearms and feet, sclerodactyly and microstomia. She displayed Raynaud's phenomenon immediately when exposed to minimal change of temperature. Pulmonary auscultation showed fine crackles in the basal part of the thorax bilaterally and oxygen saturation was $97 \%$ in the ambient air and at rest. She had regular heart beats and a holosystolic II/VI murmur in the fourth left parasternal space with increased intensity in inspiration. She had no signs of right heart failure and no vascular murmurs.

Electrocardiography showed sinus rhythm, $70 \mathrm{bpm}, \mathrm{QRS}$ axis at 60 degrees without any ST-T changes (Figure $1 \mathrm{~A}$ ).

At the 6 minutes walk test (6MWT) she stopped the test after 5 minutes due to dyspnea ( 8 on the Borg scale). She walked $336 \mathrm{~m}$ and the $\mathrm{O}_{2}$ Sat dropped from $97 \%$ to $94 \%$ (Figure 2).

Blood tests were unremarkable and the BNP (brain natriuretic peptide) levels were normal (46 pg/mL).

Transthoracic echocardiography, however, revealed normal LV systolic and diastolic function, with no significant valvular heart disease, normal sized right ventricle (RV) with good systolic function (TAPSE (tricuspid annular plane systolic excursion) $20 \mathrm{~mm}$, tissue Doppler RV free wall systolic velocity $12 \mathrm{~cm} / \mathrm{s}$, fractional area change (FAC)) $40 \%$, mild tricuspid regurgitation but an estimated pulmonary systolic pressure (PAPs) of $64 \mathrm{~mm}$. There was no pericardial effusion (Figure 3 ).

She underwent cardiac catheterization for the accurate measurement of pulmonary pressure (PAP). A significant (mean PAP $42 \mathrm{mmHg}$, systolic PAP $62 \mathrm{mmHg}$ ) precapillary (capillary wedge pressure $11 \mathrm{~mm})$ PAH was revealed with high pulmonary vascular resistance (6.27 Wood units).

Of note, a previous computer tomography (CT scan) of the thorax showed apical pulmonary tuberculosis sequelae and changes suggestive of mild fibrosis in the basal parts of the lungs.

She was considered a patient with Group 1 $\mathrm{PAH}$ and she received treatment with an endothelin receptor antagonist - Bosentan $62.5 \mathrm{mg}$ twice daily for 1 month and then $125 \mathrm{mg}$ twice daily. However, after 2 weeks of full dose Bosentan the patient presented at a local emergency room with acute dyspnea which was interpreted at the time as a respiratory tract infection. However, even after remission of the acute episode, the patient showed dyspnea at minimal exertion. She noticed a decrease in her exercise capacity since the initiation of Bosentan treatment which worsened with the uptitration of the dose.

At the current admittance, she had the same fine crackles in the lower part of the lung fields, $\mathrm{O}_{2}$ Sat in the ambient air was $96 \%$, without other changes. ECG was similar compared with previous tracings. Blood tests showed mild hypochromic microcytic anaemia and a small increase in the alanine aminotransferase (49 U/L). The BNP levels increased slightly $-59 \mathrm{pg} / \mathrm{mL}$.

At the 6MWT she stopped the test at 2.28 minutes with dyspnea graded 8 on the Borg scale. She walked $168 \mathrm{~m}$ - representing approximately $50 \%$ of the distance walked before the initiation of the PAH specific treatment. (Figure 2)

TTE was stationary compared with the previous examination with an estimated systolic PAP of $62 \mathrm{mmHg}$.

We were therefore in front of a patient with severe PAH with worsened dyspnea under specific vasodilator treatment and an episode interpreted retrospectively as acute pulmonary edema. In a 
patient with SSc the differential diagnosis includes a significant interstitial lung disease (ILD) and the patient was referred for pulmonary evaluation. The pulmonary functional tests showed preserved volumes and air flows (Forced vital capacity (FVC) $2.44 \mathrm{~L}(85.1 \%)$, forced expiratory volume in the first second (FEV1) 2 L (82.7\%), FEV1/FVC (Tiffeneau Index) 85\%, residual volume 2 L (124.4\%), total pulmonary capacity $4.85 \mathrm{~L}(104.6 \%))$ but with a severe reduction in the DLCO $(27 \%$ from predicted DLCO). As such, a ratio between FVC / DLCO $>2$ (meaning a disproportionate fall in DLCO compared to FVC) showed important PAH without sufficient arguments as to have important ILD explaining symptoms. It was then when we decided for a CT scan with contrast agent aiming at confirming the clinical suspicion of PVOD.

$C T$ scan of the thorax showed central pulmonary arterial enlargement $(35 \mathrm{~mm})$ with normal opacification, diffuse ground-glass opacification, particularly in a centrilobular distribution with septal thickening predominantly in the inferior pulmonary lobes and in the periphery, with small right pleural effusion with thickened and irregular pleura at this level, pulmonary micro nodules in the latero-basal right part $(12 / 7 \mathrm{~mm})$ and mediastinal lymph node enlargement (Figure 4). These findings are highly suggestive of PVOD and, along with the other clinical features, lead to the final diagnosis of PAH Group 1' associated with SSC.

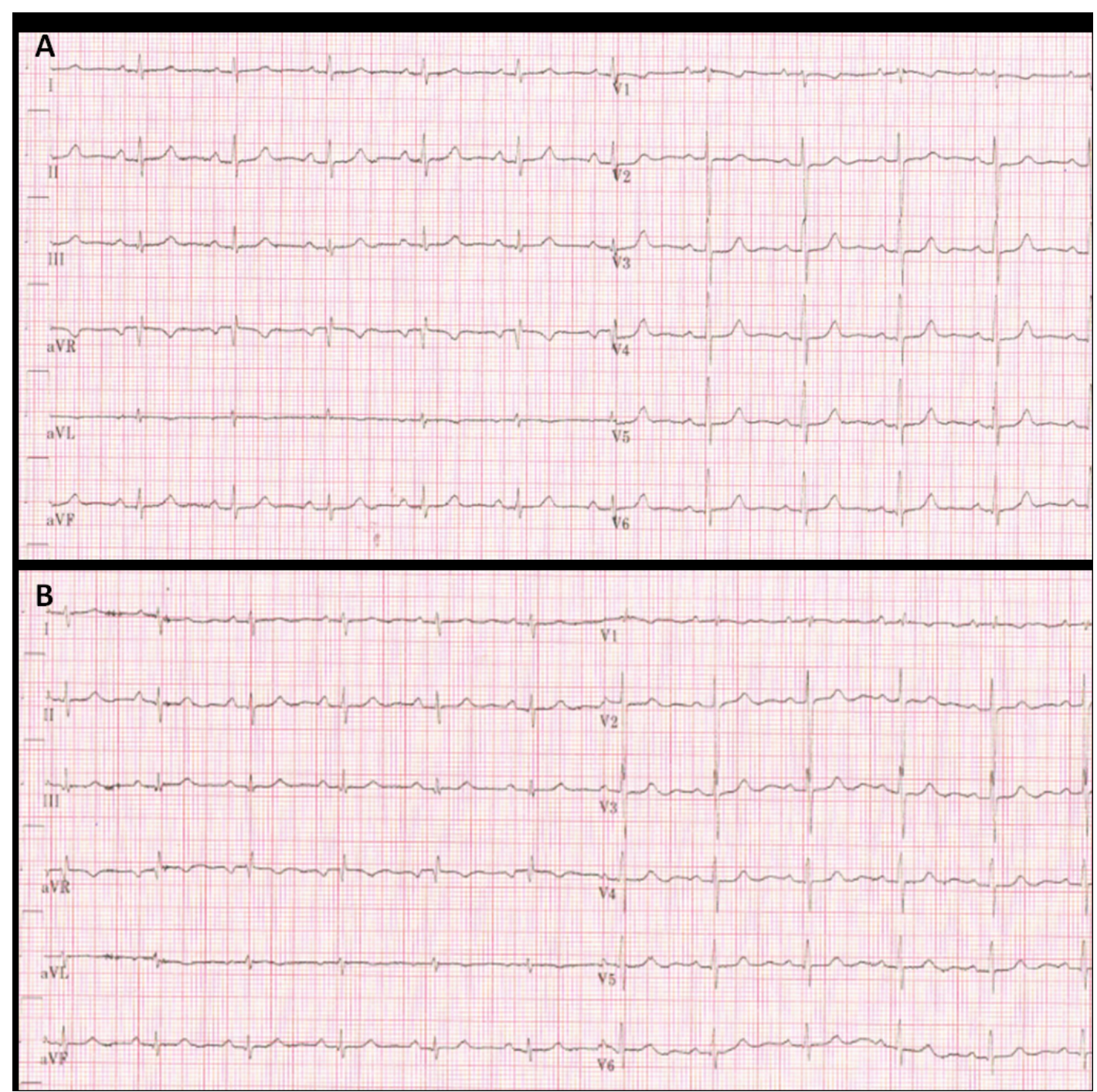

Fig. 1. A. Electrocardiogram - (A) at the first presentation showing sinus rhythm with normal QRS axis and no ST-T changes. (B) After PVOD diagnosis and 3 months after bosentan treatment discontinuation showing right QRS axis deviation with rsR' pattern in V1. 


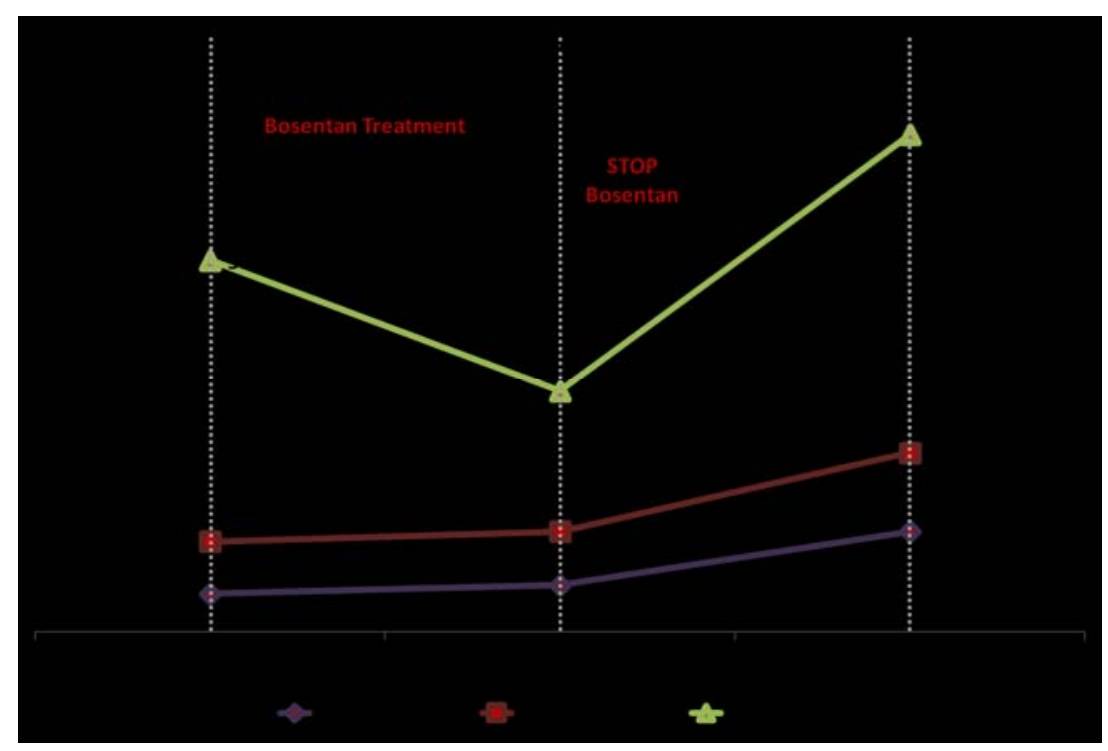

Fig. 2. Brain natriuretic peptide (BNP) levels, 6 minute walking distance (6MWD) and pulmonary systolic pressure (PAPs) on 3 separate evaluations, before Bosentan treatment ( $\mathrm{I}^{\text {st }}$ evaluation), after symptom worsening and Bosentan treatment discontinuation (II ${ }^{\text {nd }}$ evaluation) and 4 weeks after Bosentan treatment cessation (III ${ }^{\text {rd }}$ evaluation).

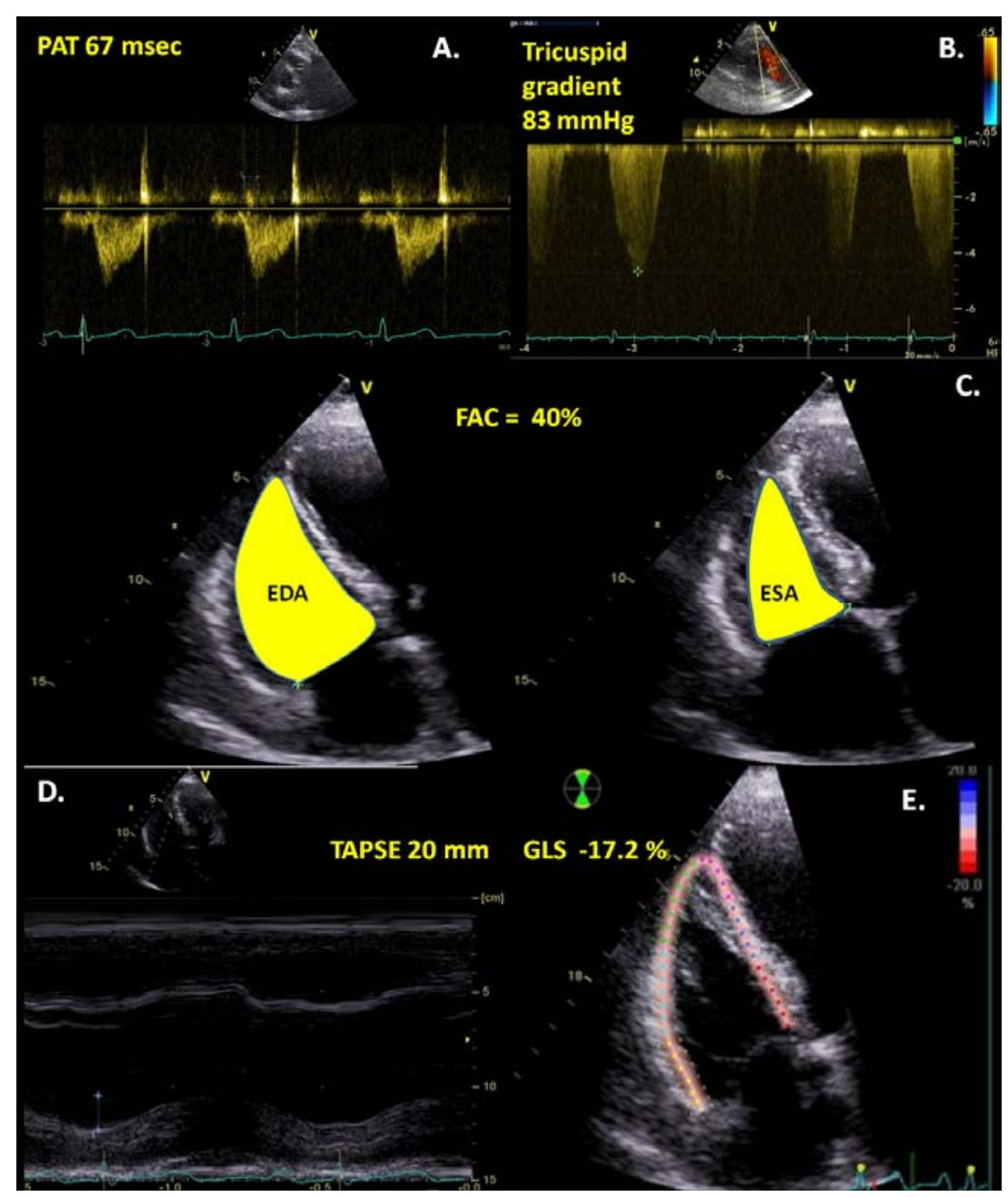

Fig. 3. Echocardiography with (A) short pulmonary acceleration time (PAT) and (B) high right ventricle (RV) to right atrium pressure gradient as signs of pulmonary hypertension. (C) Apical four chamber view modified for the RV showing a non-dilated RV with preserved global systolic function - fractional area change (FAC) $40 \%$ and longitudinal systolic function - (D) normal tricuspid annular plane systolic excursion (TAPSE) $20 \mathrm{~mm}$ as well as global longitudinal strain (GLS) of $-17.1 \%$ as measured with speckle tracking (E). 


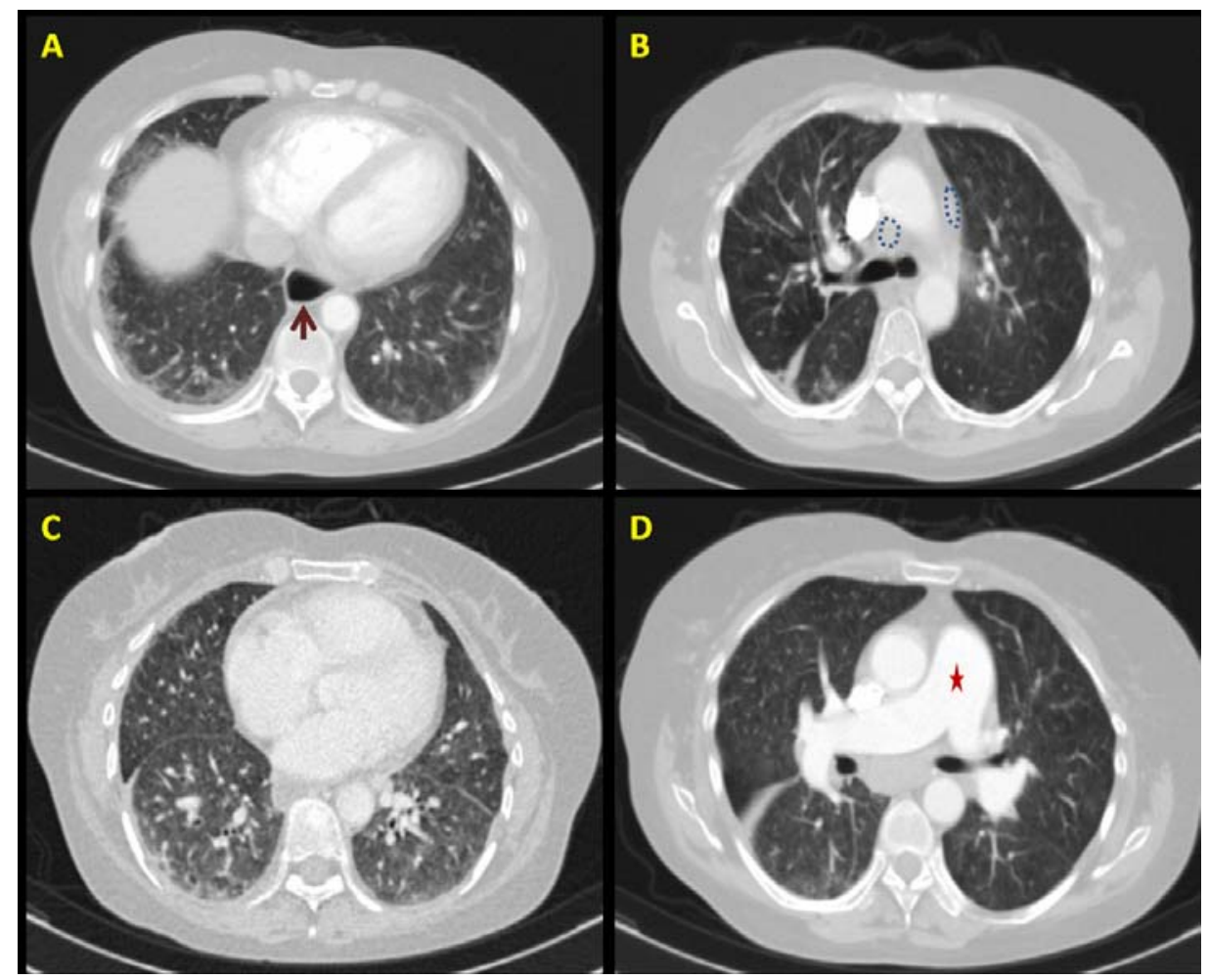

Fig. 4. Computer tomography of the chest showing (A) nodular opacities and septal line thickening predominantly in the subpleural spaces as well as a dilated oesophagus secondary to scleroderma-related dismotility (red arrow) along with mediastinal enlarged lymph nodes (dashed lines)(B). (C) Ground glass and nodular opacities with septal line thickening. (D) Enlarged pulmonary artery (red star) as another sign of pulmonary hypertension.

Therefore, Bosentan administration was stopped. Four weeks later, the patient had a better clinical status with dyspnoea at mild exertion with a 6MWT stopped after $380 \mathrm{~m}$ (representing a 50\% larger distance than the last evaluation). However, BNP levels doubled $(120 \mathrm{pg} / \mathrm{mL})$, on ECG an incomplete right bundle branch block and right axis deviation appeared (figure 1B) and echocardiography showed an increase in systolic PAP to $94 \mathrm{mmHg}$ with preserved RV systolic function (Figure 2).

The patient was referred for evaluation for pulmonary transplantation taking into account that the prognosis is dismal and the survival is less than 2 years from the time of diagnosis in this patient.

\section{DISCUSSION}

The first case of PVOD reported in the literature dates back to 1934 when the term of 'primary pulmonary sclerosis' was used [16]. Since then a lot of literature about PVOD physiopathology, diagnosis and treatment has gathered. Understanding that PAH in PVOD has morphological and therapeutic differences compared to IPAH led to a separate classification as Group 1' according to the 2008 Dana Point and later the Nice updated clinical classification of PH [1,2]. However, PVOD remains a poorly understood and underdiagnosed or late diagnosed entity with a difficult management and poor prognosis.

The etiology of PVOD remains largely unknown mostly due to its rarity and to date, pathogenesis is assumed mainly based on associations with other diseases [12,15]. A genetic factor was proposed as mutations in different loci of the type- II bone morphogenic protein receptor gene (BMPR2), a member of the transforming growth factor $\beta$ receptor superfamily, have been found in PVOD patient [17].

A toxic hypothesis has been fuelled by several case reports showing PVOD in patients exposed to several antineoplastic drugs such as mitomycin, bleomycin, cisplatin, vincristine, cyclophosphamide and carmustin $[18,19,20]$. Moreover, there is an increased incidence of PVOD in cigarette smokers compared to non-smoking patients [21]. PVOD associated to peripheral blood stem cell transplantation, bone marrow transplantation, solid organ transplantation and radiotherapy has also been reported $[7,8,22]$. 
Furthermore, PVOD pathogenesis seems to have an immunological component as well suggested by the association with several autoimmune disorders such as sarcoidosis, Langerhans' cell granulomatosis, chronic active hepatitis, Hashimoto's thyroiditis and celiac disease [14]. However, one of the most frequent associations is with connective tissue disease and, in SSc, PVOD is reported with increased frequency $[15,23]$.

The histopathological hallmark of PVOD is widespread fibrous intimal proliferation that involves predominantly the pulmonary venules and small veins, however, both the arterial and capillary components of pulmonary vasculature are often concomitantly involved and these characteristics are shared with IPAH $[24,25]$.

PVOD in SSc patients is very difficult to distinguish from PAH Group 1.4 because of the similar presenting clinical picture consisting of dyspnea on exertion, fatigue and signs of heart failure. However, oxygen saturation is usually lower and auscultatory pulmonary crackles are more frequently found in PVOD and are associated with pulmonary oedema $[2,3]$.

Definitive diagnosis is made based on histological analysis of lung biopsy specimens, however, obtaining such specimens either surgically or by transbronchial puncture are high risk procedures for these frail patients and are generally performed $[2,15,26]$.

Therefore, PVOD diagnosis is based on a non invasive approach consisting of clinical suspicion, pulmonary functional tests, high resolution CT and bronchoscopy $[2,15]$.

Cardiac catheterization is mandatory for the correct measurement of pulmonary arterial pressures. PVOD has similar invasive pressure characteristics with IPAH - precapillary PH with mean PAP at rest higher than $25 \mathrm{mmHg}$ and a pulmonary capillary wedge pressure (PWP) less than $15 \mathrm{mmHg}$ [2]. But, the normal PWP is somehow a paradox as the histological involvement is mainly in the postcapillary bed (small pulmonary veins). This paradox is explained by the PWP measurement because when the catheter is "wedged" it occludes a small artery and the pressure measured is reflecting the pressure in a vein of similar dimension. However, in PVOD, larger venules are affected and PWP appears normal as in Group 1 $\mathrm{PH}$. Therefore, this PWP does not reflect the true elevation of pressure in the small venules where PVOD histological changes occur [3].

The clinical suspicion that PAH in SSc may be due to a PVOD is mainly based on the appearance of acute pulmonary oedema after $\mathrm{PAH}$ specific therapy initiation including calcium channel blockers $[3,15,27,28]$. The mechanism involved is assumed to be related to the relative vasodilatation of the pre-capillary more than the post-capillary vessels which leads to increased blood flow and increased hydrostatic pressure in the capillaries which in turn will determine leakage into the interstitial space. Moreover, a lymphatic component has been involved, previously reported on histological specimens as well, with diminished fluid resorption [3]. Whichever the mechanism, dyspnoea aggravation under vasodilator treatment should prompt the search for PVOD in PAH patients. Our patient did not develop the full blown acute pulmonary oedema clinical picture but the severe dyspnoea after the initiation of Bosentan treatment and the symptomatic improvement after its cessation is an argument that vasodilator therapy was involved in the symptom development.

Pulmonary functional tests are useful first in diagnosing an ILD in patients with connective tissue disease as well as differentiating it from PAH changes. In PVOD as well as in PAH there are normal values of forced expiratory volume in one second (FEV1), FEV1/FVC and total lung capacity [29]. Moreover, even if it was hypothesized that DLCO could be normal in PVOD because of the frequent finding of alveolar haemorrhage, studies have shown that both PVOD and PAH have decreased DLCO, but with a much lower value in the first condition [21,30]. Furthermore, one study found a specificity of $84.5 \%$ and a sensitivity of $64.3 \%$ for a DLCO of $<55 \%$ from the predicted value to distinguish PVOD from PAH patients [21]. In our case, DLCO was severely decreased even if the lung capacities were not modified, suggesting more a PVOD than $\mathrm{PAH}$ associated to SSc.

High resolution CT (HRCT) is one of the most important tools from the panel of non invasive tests in PVOD diagnosis. The key features of PVOD on chest HRCT consists of the triad: lymph node enlargement, centrilobular groundglass opacities, and septal lines (thickened interlobular septa which are fine linear areas of 
attenuation or patterns of multiple polygonal lines) with smooth, irregular, or nodular borders [3,31]. Interestingly, one recent study showed that in SS patients with precapillary $\mathrm{PH}$, the presence of $\geq 2$ radiographic signs of PVOD can identify patients with a high risk of pulmonary oedema after initiation of PAH - specific therapy as well as with poor outcome [31]. In our patient, the CT scan showed the radiological diagnostic triad consisting in enlarged lymph nodes, ground-glass opacities and septal lines, drawing attention on the high probability to develop pulmonary edema after $\mathrm{PH}$ specific therapy. Beside the specific findings of PVOD, other signs that are common to all forms of $\mathrm{PAH}$ such as pericardial or pleural effusions, diffuse pulmonary nodules, central pulmonary arterial enlargement, RV hypertrophy and dilatation and bowing of the interventricular septum can be found. Moreover, HRCT is useful in differentiating symptoms from another more common associated disease in SS such as ILD. HRCT as well as the chest X-ray can display aspects characteristic of post capillary congestion including Kerley B lines or alveolar infiltrates in acute pulmonary oedema, but these findings can be found mostly after PAH specific therapy is initiated [2,3,31].

Bronchoalveolar lavage (BAL) can be useful in patients with SSc and PAH in which PVOD is suspected. First, it can reveal the presence of an active ILD and secondly it can add to the diagnosis of PVOD [32]. In this later case, studies have shown an increased number of hemosiderin - laden macrophages and higher average Golde score compared to idiopathic $\mathrm{PAH}$, indicating a high rate of subclinical alveolar haemorrhage in PVOD [30]. We did not perform BAL as the other investigations, including $\mathrm{CT}$ with specific findings, as well as the clinical response to bosentan interruption were considered suggestive enough to establish the diagnosis of PVOD.

Nonetheless, as stated previously, the definite diagnosis is established only by histological assessment of lung biopsy specimens which are difficult to obtain as lung biopsy is a high risk procedure in these PAH patients and is associated with increased mortality [3,15,21].

Treating these patients is even more difficult than diagnosing them. In the case of severe $\mathrm{PH}$ and signs of heart failure, PAH-specific therapy can be tried with close medical monitoring because of the high risk of acute pulmonary oedema. All classes of PAH-specific therapy have been reported to induce acute pulmonary oedema in these patients $[3,33]$. As such, careful monitoring is mandatory.

General measures are recommended in PVOD patients as in other PAH patients including immunization against influenza and pneumococcal infections and supportive measures such as long term oxygen therapy are indicated. High dose of diuretic therapy can be administered in those with signs of congestion for symptomatic benefice and to help prevent acute pulmonary oedema [2,3].

One controversial issue is that of anticoagulant treatment. In idiopathic and hereditary PAH as well as in anorexigen - induced PAH, oral anticoagulants should be considered while in associated $\mathrm{PAH}$ (including $\mathrm{SSc}$ - associated $\mathrm{PAH}$ ) they should be considered on an individual basis [2]. However, due to the frequent occult alveolar haemorrhage, in PVOD this therapy should be prescribed with caution and is contraindicated if there is a history of severe haemoptysis [3,30]. The European guideline for the diagnosis and treatment of $\mathrm{PH}$ does not give any specific recommendation for PVOD patients while for SS-associated PAH gives only a class IIa, $\mathrm{C}$ level of evidence indication for anticoagulation, therefore, we decided to withhold oral anticoagulation for the moment taking into account the risk of alveolar haemorrhage.

Immunosuppressive therapy combining glucocorticoids and cyclophosphamide may lead to clinical improvement in patients with PAH associated with connective tissue disease, however, only systemic lupus erythematosus and mixed connective tissue disease seem to benefit from this improvement while SSc don't [2].

Patients with PVOD have a poor prognosis and survival at 2 years is uncommon. The only life saving therapy is lung or heart-lung transplantation. In fact, most of the experts recommend referral for evaluation for lung transplantation at the moment of diagnosis. This was the strategy for our patient as well and an argument was the severe increase in $\mathrm{PH}$ in only 1 month after bosentan withdrawal [21].

\section{CONCLUSION}

In patients with pulmonary arterial hypertension associated to connective tissue diseases the occurrence of acute pulmonary oedema or marked 
decrease in functional capacity after the initiation of specific vasodilator therapy should prompt the search for a pulmonary veno-occlusive disease.
Management of PVOD patients is challenging and referral for lung transplantation should be done at the moment of diagnosis.

Boala pulmonară veno-ocluzivă (BPVO) este o cauză rară de hipertensiune arterială pulmonară (HTP). Datorită aspectului similar clinic îmbrăcat de BPVO şi de HTP idiopatică caracterizate prin dispnee de efort şi semne ale insuficienței cardiace drepte, cele două entități sunt dificil de diferențiat. Totuşi, distincția dintre cele două este obligatorie deoarece BPVO prezintă un prognostic mai prost decât HTP idiopatică şi, mai important, administrarea terapiei specifice pentru HTP (vasodilatatoare) poate precipita edemul pulmonar acut sever. Este prezentat un caz interesant al unei paciente diagnosticată cu sclerodermie sistemică la care diagnosticul de BPVO a fost realizat după ce capacitatea sa pulmonară s-a degradat după inițierea terapiei cu bosentan. Managementul pacienților cu BPVO reprezintă o provocare şi trimiterea către transplant pulmonar ar trebui realizată odată cu punerea diagnosticului.

Corresponding author: Ruxandra Jurcuț "Prof Dr. C.C. Iliescu” Institute of Emergency for Cardiovascular Diseases Şos. Fundeni No. 258, 022322 Bucharest, Phone: 0040-724-506434

E-mail rjurcut@gmail.com

\section{Grant support:}

This paper is supported by the Sectoral Operational Programme Human Resources Development (SOP HRD), financed from the European Social Fund and by the Romanian Government under the contract number POSDRU/159/1.5/S/137390 (AMD) and the UMF “Carol Davila” Research grant for Young Researchers project number 23348/2013 (RJ)

Conflicts of interest: none.

\section{REFERENCES}

1. SimONNEAU G, GATZOUlis MA, ADATIA I, CELERMAJER D, DENTON C, GHOFRANi A, et al. Updated clinical classification of pulmonary hypertension. J Am Coll Cardiol 2013;62:D34-41.

2. The Task Force for the Diagnosis and Treatment of Pulmonary Hypertension of the European Society of Cardiology (ESC) and the European Respiratory Society (ERS), endorsed by the International Society of Heart and Lung Transplantation (ISHLT). Guidelines for the diagnosis and treatment of pulmonary hypertension. European Heart Journal 2009; 30:2493-2537.

3. MONTANI D, PRICE LC, DORFMULLER P, ACHOUH L, JAÏS X, YAÏCI A, et al. Pulmonary veno-occlusive disease. Eur Respir J 2009; 33: 189-200.

4. MORASSUT PA, WALLEY VM, SMITH CD. Pulmonary veno-occlusive disease and the CREST variant of scleroderma. Can J Cardiol. 1992;8(10):1055-1058.

5. ZHANG L, VISSCHER D, RIHAL C, AUBRY MC. Pulmonary veno-occlusive disease as a primary cause of pulmonary hypertension in a patient with mixed connective tissue disease. Rheumatol Int 2007; 27: 1163-1165.

6. HOURSEAU M, CAPRON F, NUNES H, GODMER P, MARTIN A, KAMBOUCHNER M. Pulmonary veno-occlusive disease in a patient with HIV infection. A case report with autopsy findings. Ann Pathol. 2002;22(6):472-475.

7. WILLIAMS LM, FUSSELL S, VEITH RW, NELSON S, MASON CM. Pulmonary veno-occlusive disease in an adult following bone marrow transplantation. Case report and review of the literature. Chest 1996; 109: 1388-1391.

8. SEGUCHI M, HIRABAYASHI N, FUJII Y, et al. Pulmonary hypertension associated with pulmonary occlusive vasculopathy after allogeneic bone marrow transplantation. Transplantation 2000; 69: 177-179.

9. NUNES H, HUMBERT M, CAPRON F, et al. Pulmonary hypertension associated with sarcoidosis: mechanisms, hemodynamics and prognosis. Thorax 2006; 61: 68-74. 31

10. FARTOUKH M, HUMBERT M, CAPRON F, et al. Severe pulmonary hypertension in histiocytosis X. Am J Respir Crit Care Med 2000; 161: 216-223.

11. KHANNA D. Diagnosis and treatment of systemic and localized scleroderma. Expert Rev. Dermatol. 2011; 6(3):287-302.

12. CHAISSON NF, HASSOUN PM. Systemic Sclerosis-Associated Pulmonary Arterial Hypertension. CHEST 2013; 144(4): 1346-1356.

13. LAMBOVA S. Cardiac manifestations in systemic sclerosis. World J Cardiol 2014 26; 6(9): 993-1005. 
14. KHANNA D, GLADUE H, CHANNICK R, CHUNG L, DISTLER O, FURST DE, et al. Recommendations for Screening and Detection of Connective- Tissue Disease Associated Pulmonary Arterial Hypertension. Arthritis Rheum. 2013; 65(12): 3194-201.

15. MONTANI D, O'CALLAGHAN DS, SAVALE L, JAÏS X, YAÏCI A, MAITRE S, et al. Pulmonary veno-occlusive disease: Recent progress and current challenges. Respiratory Medicine. 2010; 104:S23eS32.

16. HORA J. Zur Histologie der klinischen "primaren Pulmonalsklerose”. Frankfurt Z Pathol. 1934; 47:100-08.

17. RUNO JR, VNENCAK-JONES CL, PRINCE M, et al. Pulmonary venoocclusive disease caused by an inherited mutation in bone morphogenetic protein receptor II. Am J Respir Crit Care Med 2003; 167(6):889e94.

18. GAGNADOUX F, CAPRON F, LEBEAU B. Pulmonary veno-occlusive disease after neoadjuvant mitomycin chemotherapy and surgery for lung carcinoma. Lung Cancer 2002; 36(2):213e5.

19. JOSELSON R, WARNOCK M. Pulmonary veno-occlusive disease after chemotherapy. Hum Pathol. 1983; 14(1):88-91.

20. LOMBARD CM, CHURG A, WINOKUR S. Pulmonary veno-occlusive disease following therapy for malignant neoplasms. Chest. 1987; 92(5):871-876.

21. MONTANI D, ACHOUH L, DORFMULLER P, et al. Pulmonary venoocclusive disease: Clinical, functional, radiologic, hemodynamic characteristics and outcome of 24 cases confirmed by histology. Medicine (Baltimore) 2008; 87: $220-233$.

22. KRAMER MR, ESTENNE M, BERKMAN N, ANTOINE M, DE FRANCQUEN P, LIPSKI A, et al. Radiation-induced pulmonary veno-occlusive disease. Chest. 1993; 104(4):1282-1284.

23. JOHNSON SR, PATSIOS D, HWANG DM, GRANTON JT. Pulmonary veno-occlusive disease and scleroderma associated pulmonary hypertension. J Rheumatol 2006; 33:2347-2350.

24. LANTUEJOUL S, SHEPPARD MN, CORRIN B, BURKE MM, NICHOLSON AG. Pulmonary veno-occlusive disease and pulmonary capillary hemangiomatosis: a clinicopathologic study of 35 cases. Am J Surg Pathol 2006; 30: 850-857.

25. DORFMULLER P, HUMBERT M, PERROS F, et al. Fibrous remodeling of the pulmonary venous system in pulmonary arterial hypertension associated with connective tissue diseases. Hum Pathol 2007; 38: 893-902.

26. NICOD P, MOSER KM. Primary pulmonary hypertension. The risk and benefit of lung biopsy. Circulation.1989; 80(5): 1486-1488.

27. PALMER SM, ROBINSON LJ, WANG A, GOSSAGE JR, BASHORE T, TAPSON VF. Massive pulmonary oedema and death after prostacyclin infusion in a patient with pulmonary venoocclusive disease. Chest 1998; 113: 237-240.

28. CREAGH-BROWN BC, NICHOLSON AG, SHOWKATHALI R, GIBBS JS, HOWARD LS. Pulmonary veno-occlusive disease presenting with recurrent pulmonary oedema and the use of nitric oxide to predict response to sildenafil. Thorax 2008; 63: $933-934$.

29. GUPTA R. Pulmonary function test as screening test for pulmonary artery hypertension in scleroderma patients. Rheumatology.2004; 43(10): 1315.

30. RABILLER A, JAIS X, HAMID A, et al. Occult alveolar haemorrhage in pulmonary veno-occlusive disease. Eur Respir J 2006; 27: 108-113.

31. GÜNTHER S, JAĎS X, MAITRE S, BÉREZNÉ A, DORFMÜLLER, SEFERIAN A, et al. Computed tomography findings of pulmonary venoocclusive disease in scleroderma patients presenting with precapillary pulmonary hypertension. Arthritis Rheum. 2012; 64(9):2995-3005.

32. MEYER KC, RAGHU G, BAUGHMAN RP, BROWN KK, COSTABEL U, DU BOIS RM, et al. An official american thoracic society clinical practice guideline: The clinical utility of bronchoalveolar lavage cellular analysis in interstitial lung disease. Am J Respir Crit Care Med 185(9):1004-1014.

33. D. MONTANI, X. JAÏS, P. DORFMULlER, G. SIMONNEAU, O. SITBON, M. HUMBERT. Goal-oriented therapy in pulmonary veno-occlusive disease: a word of caution. ERJ 2009; 34 (5):1204-1206. 